Landscape and Urban Planning 110 (2013): 175-182.

doi: 10.1016/j.landurbplan.2012.10.014

\title{
Fire-smart management of forest landscapes in the Mediterranean basin under global change
}

\author{
Paulo M. Fernandes \\ Centro de Investigação e de Tecnologias Agro-Ambientais e Biológicas (CITAB), Universidade de Trás-os-Montes \\ e Alto Douro, Apartado 1013, 5001-801, Portugal. Tel.: +351 259 350885. Fax: +351 259 350480. E-mail: \\ pfern@utad.pt
}

\begin{abstract}
Modified, more severe fire regimes are developing in the Mediterranean basin as a result of changes in land use and climate. Current fire management privileges fire suppression and tends to ignore land management issues, which may further accelerate the transition to a more fire-prone future and magnify the problem. Fire-smart management aims to control the fire regime by intervening on vegetation (fuel) to foster more fire-resistant (less flammable) and/or fire-resilient environments. Scientific knowledge supporting the creation and maintenance of fire-smart wildlands is critically reviewed, considering the landscape and the forest stand scales. Fuel management strategies (isolation, structural modification, type conversion) are discussed in regards to their current and future potential to buffer the effects of global change on the extent and severity of fires. Uncertainty in the outcomes of fire-smart management arises mainly from insufficient understanding of the relative weights of fuel and weather-drought on the fire regime. Likewise, linkage between global change processes and the fire regime is not straightforward. Shrublands and, in general, open and dry vegetation types will prevail even more in future landscapes. Decrease in biomass will limit fire incidence over parts of the Mediterranean. However, the fire regime will be largely driven by weather, advising concentration of fuel management efforts in wildland-urban interfaces and in forests and their vicinity; decrease of landscape fire severity rather than area burned as the objective; prescribed burning as the treatment of choice, except in the wildland-urban interface; and focus on forest types that are fire-resilient irrespective of flammability.
\end{abstract}

Keywords:

Fire risk; Fire resiliency; Fuel management; Fuel treatments; Climate change; Land use change

\section{Introduction}

The Mediterranean Basin (MB) comprises the lands that in Europe, Africa and Asia border the Mediterranean Sea (Fig. 1) and have mild, humid winters and warm, dry summers, i.e. are defined by a Mediterranean-type climate. The MB is highly diverse in geography and topography and its landscapes have long since been manipulated, resulting in complex vegetation and land use mosaics (Scarascia-Mugnozzaa, Oswald, Piussic, \& Radoglou, 2000). 
Wildland fire is an important element of Mediterranean landscapes and ecosystems. Landscape diversity and the intensity of biomass use in the MB controlled fire incidence in the past, its contemporary increase being presumably fuel-driven, i.e. caused by changes in land cover and land use (Moreira et al., 2011; Pausas \& Fernández-Muñoz, 2011). Fires are selective for and grow larger in less pyrodiverse landscapes (Loepfe, Martinez-Vilalta, Oliveres, Piñol, \& Lloret, 2010; Viedma, Angeler, \& Moreno, 2009). Several authors reviewed in Moreira et al. (2011) describe the last decades processes leading to stand-level fuel accumulation and landscape fuel connectivity in the MB: the mosaic structure of the landscape largely collapsed, due to agriculture abandonment and expansion of forests and shrublands, and forest management and grazing livestock have generally decreased. Wildland-urban interfaces (WUI) have greatly expanded in the MB in the last decades. The coalescence of flammable vegetation and urban development and the high risk of ignition in these areas imply extreme threat to human life and property (Moreira et al., 2011). Also, fire activity increased in parallel with the severity of the meteorological component of fire risk during the second-half of the 20th century. Seidl, Schelhaas, \& Lexer (2011) contend that climate change, rather than forest-related change, is the main driver behind the fire regime modification, especially in the Central and Eastern MB. However, evidence is mounting that the positive response of fire to more extreme weather and drought events is mediated by vegetation-fuel (Koutsias et al., 2012; Pausas \& Fernández-Muñoz, 2012; Pausas \& Paula, 2012).

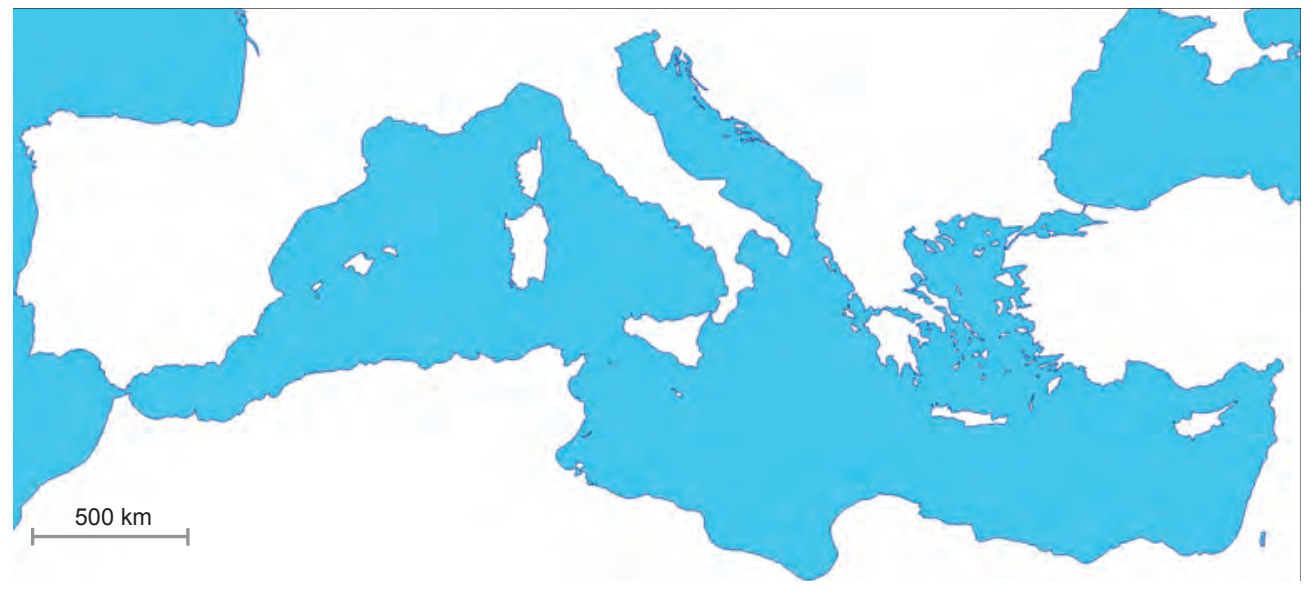

Fig. 1. The Mediterranean basin.

Fire management policies in the MB rely heavily on fire suppression and do not sufficiently address the socio-economic and land management issues behind the inception and spread of fires (Fernandes, 2008). Fire control technology succeeds only within the lower range of fire intensity (Gill, 2005). The effectiveness of fire fighting operations is therefore greatly reduced when unfavourable weather and fuel accumulation coincide. In fact, because a fire suppression policy is conducive to fuel build up and more intense fires, it can ultimately contribute to larger and more severe fires (Fernandes, 2008; Piñol, Castellnou, \& Beven, 2007).

Hirsch et al. (2001) defined fire-smart forest management as an integrated approach primarily based on fuel treatments through which the socio-economic impacts of fire are minimized while its ecological benefits are maintained and maximized; by lowering 
ignition likelihood and fire behaviour potential, fire suppression capacity is increased and forests and landscapes become more resistant to fire spread and more resilient to its occurrence. Fires, including of natural origin, are seldom allowed to spread in cultural landscapes (such as the MB) and "fire smartness" is attained through proactive management by treating fuels in fire-prone vegetation types or decreasing the importance of those vegetation types in the landscape (Pyne, Andrews, \& Laven, 1996). On-going and future climate change makes these topics even more relevant. MB forests will adapt to climate change with difficulty, and their protection from wildfire will be important and require large-scale fuel management (Alcamo et al., 2007). Fuel management is deemed the single most important adaptation measure of MB forests to climate change (Kolström, Vilén, \& Lindner, 2011).

The ultimate goal of fire management is to modify the fire regime, which results from the interaction between ignitions and the fire environment, i.e. topography, weather and vegetation (fuels). By addressing the fuel component, fire-smart forest management is expected to decrease area burned both directly and indirectly, respectively by delaying fire spread and by expanding the weather scenarios under which wildfire control is feasible. An additional goal - often more relevant or realistic - is to increase tree resistance to fire and decrease the impact (severity) of fire, thus increasing tree survival and the ability to recover from disturbance (Reinhardt, Keane, Calkin, \& Cohen, 2008). Differentiation between fuel management strategies considers fuel isolation by fuel-breaks, fuel modification in quantity and/or structure, and conversion to less flammable fuel types (Pyne, Andrews, \& Laven, 1996). Fuel isolation and fuel modification can be respectively viewed as linear and area-wide options for treating fuels and presuppose different expectations, respectively fire containment and fire modification (Finney, 2001), whereas type conversion is appealing because it changes the landscape fire-carrying capacity by simply changing vegetation composition.

This paper offers a state of the art on the science behind fire-smart management of MB forest landscapes in relation to global change as the combination of climate and land use changes. Landscapes are perceived here as heterogeneous and visible areas of variable size that integrate environmental processes (Nassauer, 2012). Fuel management strategies are discussed from the perspective of their current and future effectiveness to counteract the adverse effects of altered fire regimes to ecosystem and landscape structure, composition and function.

\section{Fire size and incidence as affected by fuel treatments}

Linear fuel treatments are the prevailing option in the MB (Xanthopoulos et al., 2006), but their performance in face of fire is uncertain. Fuel-breaks are inconsequential if they fail to inhibit or delay fire spread. As with any other fuel management approach, the success of fuel isolation is dependent on its design, which should carefully consider the width, length and spatial arrangement of strips (Finney, 2001). Perchat \& Rigolot (2005) analysed the 2003 wildfires in southern France and found out that most fuel-breaks were crossed or transposed by high-intensity fire. Still, they note that headfire growth was delayed and that fire flanks were generally restrained by fuel breaks perpendicular to the direction of fire spread. An extensive study in southern California showed that fires are seldom stopped by fuel breaks in the absence of fire fighters, other relevant factors being 
fire size and season (surrogates for weather) and fuel-break condition (Syphard, Keeley, \& Brennan, 2011).

Case studies of the effects of fuel treatments on large fire growth do exist, e.g. Finney, McHugh, \& Grenfell (2005). However, understanding of the effects of fuel treatments at the scale of the landscape is mostly theoretical and relies heavily on fire simulation modelling (Finney, 2001). The long-term, cumulative impacts of fuel management on fire incidence depend on how the rates of treatment effort and fuel re-accumulation relate with each other (Finney et al., 2007; King, Bradstock, Cary, Chapman, \& Marsden-Smedley, 2008). Fire modelling can then provide decision-support to the temporal and spatial planning of fuel treatments by allowing analysis of the landscape fire-spread potential in response to variation in fuels and other factors (Duguy, Alloza, Röder, Vallejo, \& Pastor, 2007). After defining how much of the landscape is to be treated annually, the size and location of treatments and the overall spatial arrangement and frequency of treatment can be optimized to disrupt fire spread the most (Collins, Stephens, Moghaddas, \& Battles, 2010).

The relative influences of fuel and weather in shaping the fire regime differ by ecosystem type. If fuel has but a minor role in wildfire incidence it follows that the rationale for investing in large-scale fuel management programs is weak. Control of the fire regime by fuel is expected to increase with aridity, because moisture regulates fuel loading and its availability to burn (Pausas \& Bradstock, 2007). With the exception of more arid and windsheltered environments, the dependency of burn probability on time, i.e. on fuel accumulation, is moderate at best in Mediterranean-type shrublands (Fernandes, Loureiro, Magalhães, Ferreira, \& Fernandes, 2012; Moritz, Keeley, Johnson, \& Schaffner, 2004; O'Donnell, Boer, McCaw, \& Grierson, 2011; Oliveira, Pereira, \& Carreiras, 2012; Van Wilgen et al., 2010). Shrublands are crown fire systems - implying that fire control is difficult at relatively mild weather conditions - and their structure and flammability recover fast after disturbance (Marino, Guijarro, Hernando, Madrigal \& Díez, 2010). In forests, and although understorey and ladder fuels take longer to recover, litter is determinant for fire spread and typically returns to its pre-treatment levels in 2-5 years (Fernandes \& Botelho, 2003), except in certain short-needled conifer forests where fire spread is a self-limited process (Collins et al., 2009). Hence, it is no surprise that under more extreme weather conditions wildfires can override fuel-age mosaics in chaparral (Keeley \& Zedler, 2009) and burn over recently prescribed burnt areas in eucalypt forest (Price \& Bradstock, 2010).

Area-wide fuel treatments have a passive effect on fire spread and will decrease the area burned per unit of time irrespective of fire suppression. However, the previous paragraph suggests that a substantial treatment effort is needed to significantly decrease wildfire incidence. Boer, Sadler, Wittkuhn, McCaw, \& Grierson (2009) and Price \& Bradstock (2011) quantified the return for effort of prescribed burning in Australian eucalypt florests, and report that 3-4 units of prescribed fire are required to lessen wildfire area by one unit. A more favourable ratio of 1:2 to 1:1 was found by Vilén \& Fernandes (2011) for the more fragmented and human-influenced forest landscapes of Portugal, but it expresses the general effect of fuel on fire incidence, as it was based solely on wildfire data. The simulation experiment of Cochrane et al. (2012) showed that the performance of fuel treatments cannot be generalized, because treatments redistribute burn probability in the landscape by inhibiting or enhancing fire spread; on average, a $-7.2 \%$ net effect on fire size was estimated for 14 large wildfires that encountered 1300 individual fuel treatment units in the U.S. 


\section{Fire behaviour and severity in fuel-treated forest stands}

When contrasted with linear treatments, a striking effect of area-wide treatments is the heterogeneity in fire behaviour and severity across the landscape. Consequently, area treatments will be beneficial if they succeed in mitigating fire severity, regardless of impacting or not on the extent of fires (Reinhardt, Keane, Calkin, \& Cohen, 2008). Quantitative evidence of differences in fire behaviour and severity between alternative fuel treatments or in treated versus untreated stands can only be obtained by actually observing fires and their aftermath. However, experimental studies of fire behaviour and effects in relation to fuel treatments have been extremely scarce worldwide. High-intensity fire experiments in SW Australia dry eucalypt forest demonstrated increases in fire behaviour characteristics for up to 10-15 years after prescribed burning (McCaw, Gould, Cheney, Ellis, \& Anderson, 2012). In Portugal, a drastic change from crowning to relatively mild surface fire was observed when an experimental summer fire moved from an untreated Pinus pinaster stand to areas that had been prescribed burnt 2-3 years ago (Fernandes, Loureiro, \& Botelho, 2004); a related study (Fernandes, 2009a) found lower surface fire intensity in prescribed burnt plots for at least 10 years after treatment.

Guidelines and prescriptions for treatment are largely derived from sources other than the scant number of experiments addressing fuel-treatment effectiveness: fire modelling, which allows simulation of fire behaviour characteristics for different fuel and stand management scenarios (e.g. Cruz, Alexander, \& Fernandes, 2008) but may not be reliable enough (Cruz \& Alexander, 2010); data from wildfire case studies, scarce and usually limited in scope; inference from fire-resistant forest stands, i.e. where fire-induced tree injury and mortality are mitigated to some degree; and expert knowledge, which can be analysed to relate fire hazard with stand and fuel structure (González, Kolehmainen, \& Pukalla, 2007a).

Fire-smart silviculture in the dry conifer forests of western North America implements the following fuel treatment principles and priorities to increase resistance to fire (Agee \& Skinner, 2005; Graham, McCaffrey, \& Jain, 2004):

1. Decrease the accumulation or modify the structure of surface fuels to limit potential fire intensity, hence decreasing tree injury and facilitating effective fire suppression.

2. Raise the canopy base by pruning the trees and remove ladder fuels, minimizing the likelihood of vertical fire development, i.e. passive crown fire.

3. Thin the stand to decrease foliage density, impeding the transmission of fire between adjacent trees, i.e. active crown fire.

4. Maintain large trees of fire resistant species.

This sequence is coherent with fire-behaviour development stages and can be used as a guideline to treat flammable types of forest elsewhere. Supporting evidence for this approach is provided by a wealth of North-American studies documenting how wildfire severity is mitigated in continental and mediterranean conifer forests treated with prescribed burning and/or thinning (Agee \& Skinner, 2005; Finney, McHugh, \& Grenfell, 2005; Prichard, Peterson, \& Jacobson, 2010; Safford, Stevens, Merriam, Meyer, \& Latimer, 2012; Strom \& Fulé, 2007;). Fire resiliency is further enhanced by spatial heterogeneity in stand structure, as shown by unmanaged old-growth forests frequently disturbed by surface fire (Stephens, Fry, \& Franco-Vizcaíno, 2008; Stephens \& Fulé, 2005; Stephens, Millar, \& Collins, 2010). Similar patterns seem to occur in the Iberian Peninsula, where 
mature and uneven-aged pine stands persist locally under a regime of low to moderate fire severity (Fulé, Ribas, Gutiérrez, Vallejo, \& Kaye, 2008).

Removal or modification of the fuels resulting from tree pruning and thinning is mandatory, or the decrease in crown fire potential will be outweighed by an increase in surface fire intensity, e.g. Raymond \& Peterson (2005). Overstorey fuel treatments tend to create a drier, warmer and windier environment (Ma, Concilio, Oakley, North, \& Chen, 2009), which in turn will worsen surface fire behaviour and frustrate the treatment objective (Graham, McCaffrey, \& Jain, 2004). In this respect Alvarez, Gracia \& Retana (2012) note that while active crown fires were absent from open stands of $P$. halepensis in Spain, passive crown fires were more prevalent there than in moderately dense stands. Similarly, Oliveras, Gracias, Moré, \& Retana (2009) and Róman-Cuesta, Gracia, \& Retana (2009) report an association between surface fire and higher pine canopy cover. Some studies indicate that thinning has a small or irrelevant impact at the low end of the fuel moisture content range (Pook \& Gill, 1993; Faiella \& Bailey, 2007), which points to wind as the major factor involved in the post-treatment increase of surface fire potential. Flammable shrubs are an important factor in fire intensity and tree damage (e.g. Stephens, Fry, \& Franco-Vizcaíno, 2008) and often dominate the understorey in MB forests. Hence, tree canopy opening might favour shrub development and as such will increase fire hazard, especially in more productive sites, which underlines the need to combine or coordinate surface and crown fuel treatments (Graham, McCaffrey, \& Jain, 2004).

Regardless of the immediate or delayed fire environment modifications brought by the silvicultural treatment, its effectiveness (from a fire suppression viewpoint) can be gauged by the ability to prevent crowning (Keeley et al., 2009). More generally, the practical effect of a fuel treatment will persist as long as transition to crown fire is inhibited, e.g. crowning is unlikely in 1-5 - year old fuels in SE Australia eucalypt forest under extreme weather (Bradstock, Hammill, Collins, \& Price, 2009). In any case, wildfire study cases testify to the value and potential of silviculture to mitigate fire behaviour and fire severity in pine plantations (Fernandes \& Rigolot, 2007).

\section{Fire incidence and severity in relation to forest composition}

The nature, quantity and arrangement of fuels changes with forest composition in species, inducing variation in potential fire behaviour and thereby providing the rationale for cover type conversion. Conventional wisdom assumes that some forest types, namely deciduous broadleaves, are effective at modifying fire behaviour and disrupting landscape fire spread. Fire modelling and fire selectivity studies support such hypothesis (Fernandes, 2009b; Moreira, Vaz, Catry, \& Silva, 2009; Moreno, Viedma, Zavala, \& Luna, 2011). In NE Spain, Díaz-Delgado, Lloret, \& Pons (2004) report a decrease in fire incidence from pine to evergreen broadleaved to deciduous broadleaved forests, and González, Palahi, Trasobares, \& Pukalla (2006) found that broadleaves (Quercus robur, Q. ilex) and short-needled mountain pines were less fire prone than the more flammable pine species.

The implications of forest composition to fire incidence and to fire severity should be comparable, because both depend on fire behaviour. Nevertheless, documentation of fire severity in relation to stand composition has been surprisingly scarce in southern Europe. The empirical analysis of fire severity is additionally complicated by the confounded effects of topographical position, fire spread pattern and stand structure (Broncano \& Retana, 
2004; Fernandes, Luz, \& Loureiro, 2010; Oliveras, Gracia, Moré, \& Retana, 2009). Local meteorology and the fuel complex are both affected by stand structure. Stand characteristics can then minimize or on the contrary exacerbate the effect of forest composition on fire behaviour, whereby fire hazard variation is similar between and within forest types (Fernandes, 2009b).

Fernandes, Luz, \& Loureiro (2010) compared fire severity between Pinus pinaster, a highly flammable species, and adjacent stands of other cover types in northern Portugal. Metrics adjusted for the effects of other factors revealed a fire severity gradient where $P$. pinaster > deciduous broadleaves > short-needled conifers. In the same region, Proença, Pereira, \& Vicente (2010) reported lower canopy fire severity in a broadleaved forest of Quercus robur - Ilex aquifolium in comparison with pine forest (P. pinaster, P. sylvestris). Deciduous hardwood forests in non-Mediterranean ecosystems display lower magnitude in fire behaviour and effects when compared with conifers (e.g. Epting \& Verbyla, 2005).

Resilience to fire is determined by the interaction between fire severity and plant traits involved in the post fire response. Research on post fire tree mortality patterns is therefore an important supplement to fire severity studies. The description and prediction of fire-induced tree mortality has recently gained momentum in southern Europe, covering the entire fire severity range and addressing both pine and broadleaved species, especially oaks (Catry, Rego, Moreira, Fernandes, \& Pausas, 2010; González, Trasobares, Palahi, \& Pukkala, 2007b; Moreira, Duarte, Catry, \& Acácio, 2007; Vega, Jimenez, Vega, Ortiz, \& Pérez, 2011). The most fire-resilient types are those that quickly recover from high-intensity fire - species able to sprout from the crown, i.e. Quercus suber and Pinus canariensis - and those associated to low flammability environments (deciduous broadleaves and mountain conifers), provided that fire-resistance traits (namely bark thickness) are sufficiently developed to assure tree survival.

\section{Global change, the fire regime, and fire-smart management}

Wildland fire activity both contributes to and is impacted by climate change (Bowman et al., 2009). Future climate-driven increases in fire risk are expected globally (Pechony \& Shindell, 2010), in Europe (Schelhaas et al., 2010; Anav \& Mariotti, 2011; Dury et al., 2011) and in the MB (Moriondo et al., 2006). However, downscaling from synoptic climate models to the local weather that drives fire behaviour is beyond the current understanding of processes (Macias Fauria, Michaletz, \& Johnson, 2011). Several empirical and modelling studies predict significant future increases in fire extent or frequency by extrapolating the current relationships between weather-climate and fire activity (e.g. Carvalho et al., 2010). Such predictions neither consider the concurrent changes in vegetation-fuel and in firerelated human activities nor the complex interactions involved (Hessl, 2011) that processbased fire models are only beginning to tackle (Thonicke et al., 2010). As a consequence, the fire regime implications of global change remain uncertain and are potentially varied (Bradstock, 2010; Flannigan, Krawchuk, de Groot, Wotton, \& Gowman, 2009; Moritz \& Stephens, 2008).

Fig. 2 schematizes the effects of global change on anthropogenic fire regimes. Burnable biomass has a chief role through its effect on fire behaviour and depends of vegetation type and species composition, fuel structure and loading, and fuel moisture (mainly drought dependent) (Bradstock, 2010; Hessl, 2011). The responses of vegetation 
and fuel to climate change are a major factor of uncertainty, depending on how, and to what extent, productivity (including the direct effect of more $\mathrm{CO}_{2}$ in the atmosphere) and decomposition will be changed. Minor increments in net primary production (NPP) are predicted for MB landscapes, but aridity will increase in parts of the region (Anav \& Mariotti, 2011). In general, open and drought-adapted vegetation types will be more prevalent (Alcamo et al., 2007; Dury et al., 2011; Resco de Dios, Fischer, \& Colinas, 2007), with shrubland and open woodland expansion at the expenses of both pine and oak forest. Despite its general decline, evergreen sclerophylous woodland is expected to replace grassland in some parts of the western $\mathrm{MB}$ and displace deciduous forests (Anav \& Mariotti, 2011; Dury et al., 2011), which in turn may move into treeless higher elevations (Resco de Dios, Fischer, \& Colinas, 2007).

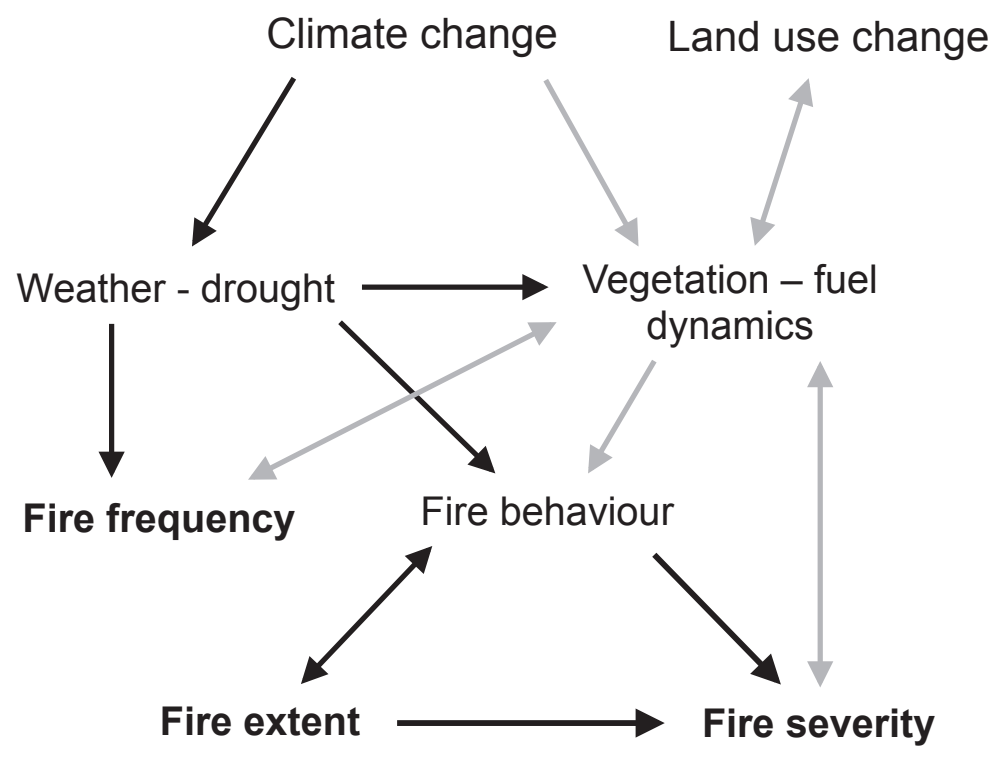

Fig. 2. Global change effects on the main fire regime elements in systems dominated by anthropogenic ignition. Interrelationships are modified and expanded from Fox \& Fox (1987). Black arrows denote processes that lead to increases in the frequency, extent or severity of fire. Grey arrows are assigned to processes that can either increase or decrease fire frequency, extent or severity.

In the absence of fuel-related constraints, future patterns in weather-drought will potentially threaten both serotinous (Pinus pinaster, P. halepensis, P. brutia) and nonserotinous ( $P$. nigra, $P$. sylvestris) pines, respectively by allowing higher fire frequency and higher fire severity (Pausas, Llovet, Rodrigo, \& Vallejo, 2008). While this modified fire regime favours oaks over pines in mixed forests, it will degrade populations of even the most fire-resilient oak, Quercus suber (Acácio, Holmgren, Rego, Moreira, \& Mohren, 2009; Schaffhauser, Curt, \& Tatoni, 2011). Consequently, as both a direct and an indirect effect of climate change, shrubland will be an even more prominent feature of MB landscapes.

Current evidence points to a late $20^{\text {th }}$ century shift from a fuel-limited fire regime to a drought-controlled fire regime in the western $\mathrm{MB}$, due to land use changes (Pausas \& 
Fernández-Muñoz, 2012; Pausas \& Paula, 2012). Although climate-altered fire incidence in the MB will become more fuel-limited where fuel loading decreases (Krawchuk, Moritz, Parisien, Van Dorn, \& Hayhoe, 2009), increased NPP will be the dominant trend in shrubland (Osborne, Mitchell, Sheehy, \& Woodward, 2000). Increase in shrubland extent and in shrub-dominated woodland where extreme weather events are or will become more frequent imply a more weather-dependent fire regime, hence less likely to respond to fuel management, as described in section 2. However, not all Mediterranean-type shrublands are expected to behave like California chaparral in respect to the relative weights of weather and fuel as fire-spread drivers. In Portugal, the dependency of burn probability on fuel age decreases at a modest rate with fire size and fire weather severity (Fernandes, Loureiro, Magalhães, Ferreira, \& Fernandes, 2012). In any case, current understanding recommends a concentration of fuel treatment efforts in forests and at the forest-shrubland interface. Managing unplanned fires, i.e. conditioning fire suppression to potential fire severity and values at risk, might be an effective option for shrubland, especially in more remote areas. Such approach is congruent with maintaining shrubland structure and function, offsetting further shifts to more flammable and less resilient systems (Pausas, Llovet, Rodrigo, \& Vallejo, 2008).

Adaptive strategies to climate change should seek higher ecosystem resistance and resilience to fire (Moritz \& Stephens, 2008; Reinhardt, Keane, Calkin, \& Cohen, 2008; Stephens, Millar, \& Collins, 2010), implying preference for area-wide fuel modification and cover type conversion. The protection requirements of flammable forest plantations are particularly high, and in fire-prone regions oblige to the implementation of costly fuel modification (Fernandes \& Rigolot, 2007). A variety of factors restrict large-scale fuel management (Collins, Stephens, Moghaddas, \& Battles, 2010), of which the typically low timber profitability of $\mathrm{MB}$ forests is noteworthy, especially as rural abandonment is expected to persist in the near future (Verburg, Berkel, Doorn, Eupen, \& Heiligenberg, 2010). Consideration of both fire risk and economic objectives in the forest planning process can be used to define rotation length and schedule silvicultural and fuel treatments such that resistance to fire and net income are reconciled (e.g. González-Olabarria \& Pukkala, 2011). Finally, it is worth considering that fuel treatments, regardless of the effect on subsequent fires, can promote ecosystem health under climate change (Millar, Stephenson, \& Stephens, 2007).

Because civil protection takes precedence over forest protection, WUI obtain a disproportionally higher allocation of fire management efforts, now and in the foreseeable future. This further restricts the amount of non-WUI land that can be subjected to fuel treatments, potentially leading to larger and more severe fires and higher area burned. Nevertheless, a fire suppression trade-off favourable to forests and shrublands is possible, because fuel treatments in the WUI create "defensible space" or "asset protection zones" (Gill \& Stephens, 2009) and diminish the fire-fighting resources needed for effective protection. Fuel management regulations for the WUI do exist in MB countries, but treatment implementation is often poor (Moreira et al., 2011), probably because of resource limitations, insufficient awareness by residents and weak law enforcement (Reams, Haines, Renner, Wascom, \& Kingre, 2005; Gill \& Stephens, 2009).

The social acceptance and operational feasibility of prescribed burning in the WUI are low and will likely remain so. However, prescribed burning expansion in other areas would decisively contribute to larger-scale fuel management in the MB, with the putative added 
value of improving the carbon balance in fire-prone forest landscapes (Narayan, Fernandes, van Brusselen, \& Schuck, 2007; Vilén \& Fernandes, 2011). Nevertheless, the potential of prescribed fire to mitigate $\mathrm{CO}_{2}$ emissions depends on how the fire regime is changed, especially in terms of the overall area burned and fire intensity (Bradstock \& Williams, 2009). More generally, fuel and stand treatments that target fire resistance benefit the long-term stability of carbon stocks, as evidenced by western USA studies, e.g. Hurteau, Stoddard, \& Fulé (2011).

Either natural or artificial forest conversion to less flammable and more mesic cover types will be increasingly difficult under climate change. However, similarly low fireseverity levels occur in relatively dense and mature stands of short-needled mountain conifers and sclerophylous broadleaves characterized by compact litter (Fernandes, Luz, \& Loureiro, 2010). The post fire sprouting ability of sclerophylous oaks confers resilience to fire regardless of flammability (Pausas, Llovet, Rodrigo, \& Vallejo, 2008) (Fig. 3); these relatively open and dry (more fuel-limited) forests and woodlands should in any case be amenable to less stringent fuel treatments than required by conifer forest types prone to crown fire. Finally, reforestation after high-severity fire provides an opportunity to facilitate transition and response to climate change through stand establishment and management practices that promote heterogeneous composition and structure as well as flexibility in the response to disturbance (Stephens, Millar, \& Collins, 2010).

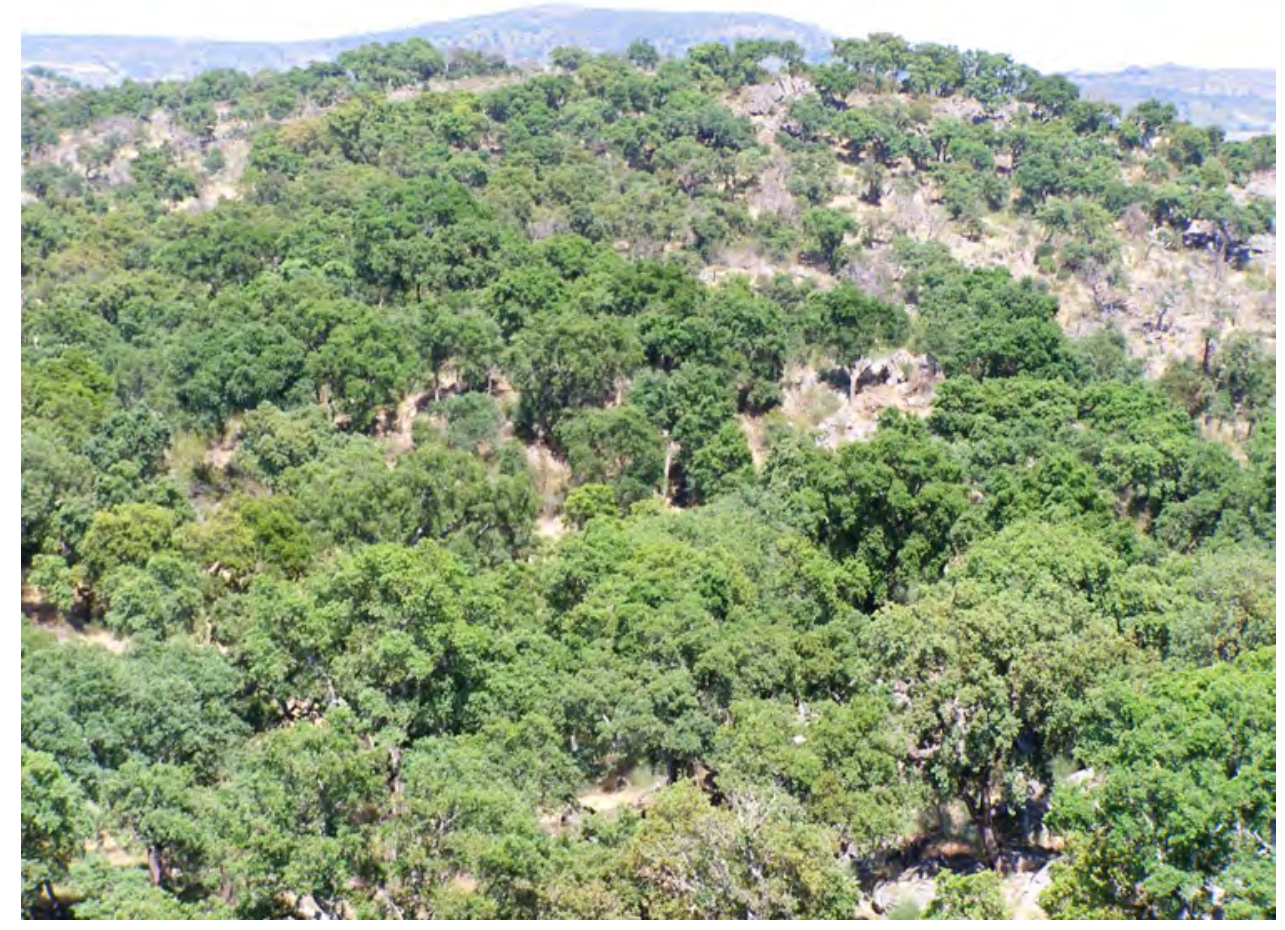

Fig. 3. Flammable but resilient to fire: cork oak (Quercus suber) woodland 11 years after moderateto high-severity wildfire, NE Portugal. Tree mortality is minimal, crown recovery is fast and regeneration is abundant. 


\section{Conclusion}

Fire policies in the MB are centred on fire suppression, which makes them unsustainable and often counterproductive. It is now recognized that short-term and reactive fire control policies should give way to "longer-term policies aimed at acting on the structural causes of fires and integrating fire and forest management strategies" (EFI, 2010). In order to support integrated fire management, a stronger research effort is required in regards to landscape fire spread, mitigation of immediate fire effects in forest stands, and the resilience of different forest types in relation to variation in the fire regime.

Fuel management, including the planned use of fire, deserves a more prominent role in fire management. The effects and effectiveness of treating surface fuels in forests are well established and quantified. Conversely, guidelines and practices to manage forest structure for the silvicultural prevention of fire are quantitatively incipient. Learning from wildfires, experimenting with fire or using simulation tools are the basic options available to refine fire-smart silviculture and expand the ability to develop sound prescriptions.

Prospects for decreasing the incidence of fire under climate change may well be unrealistic. Accordingly, fire-smart management should target the mitigation of fire severity on the landscape, achieved through area-wide fuel treatments and fuel type conversion (preferably to vegetation types that are fire-resilient regardless of flammability) rather than by fuel isolation. The spatial features of fuel management are critical, as random patterns can moderate the local effects of wildfire but have no impact on its growth. Furthermore, and as the MB becomes a more fire-prone environment due to continuing rural abandonment and climate change, it will be advisable to consider the management of unplanned fires, both as a fuel treatment and an ecological process.

\section{Acknowledgments}

This work is financed by the ERDF - European Regional Development Fund through the COMPETE Programme (operational programme for competitiveness) and by National Funds through the FCT - Fundac, ão para a Ciência e a Tecnologia (Portuguese Foundation for Science and Technology) within project FIRE-ENGINE - Flexible Design of Forest Fire Management Systems/MIT/FSE/0064/2009. The paper contributes to COST Action FP0701 "Post-fire Forest Management in Southern Europe" and evolved from a keynote lecture given at the EFIMED Progress Meeting and Scientific Seminar on Knowledge-based Management of Mediterranean Forests Under Climate Driven Risks: the Ways Ahead (April 2010, Antalya, Turkey). Juli Pausas, José CardosoPereira and the anonymous reviewers are acknowledged for their comments.

\section{References}

Acácio, V., Holmgren, M., Rego, F., Moreira, F., Mohren, G.M.J., 2009. Are drought and wildfires turning Mediterranean cork oak forests into persistent shrublands? Agroforestry Systems, 76, 389-400.

Agee, J., Skinner, C., 2005. Basic principles of forest fuel reduction treatments. Forest Ecology and Management, 211, 83-96.

Alcamo, J., Moreno, J.M., Nováky, B., Bindi, M., Corobov, R., Devoy, R.J.N., Giannakopoulos, C., Martin, E., Olesen, J.E., Shvidenko, A., 2007. Europe, in: Parry, M.L., Canziani, O.F., Palutikof, J.P., van der Linden, P.J., Hanson, 
C.E. (Eds.), Climate Change 2007: Impacts, Adaptation and Vulnerability. Contribution of Working Group II to the Fourth Assessment Report of the Intergovernmental Panel on Climate Change. Cambridge University Press, Cambridge, UK. pp. 541-580.

Alvarez, A., Gracia, M., Retana, J., 2012. Fuel types and crown fire potential in Pinus halepensis forests. European Journal of Forest Research, 131, 463-474.

Anav, A., Mariotti, A., 2011. Sensitivity of natural vegetation to climate change in the Euro-Mediterranean area. Climate Research, 46, 277-292.

Boer, M.M., Sadler, R.J., Wittkuhn, R., McCaw, L., Grierson, P.F., 2009. Long-term impacts of prescribed burning on regional extent and incidence of wildfires - evidence from fifty years of active fire management in SW Australian forests. Forest Ecology and Management, 259, 132-142.

Bowman, D.M., Carlson, J.M., Cochrane, M.SA., D’Antonio, C.M., DeFries, R.S., Doyle, J.C., Harrison, S.P., Johnston, F.H., Keeley, J.E., Krawchuk, M.A., Kull, C.A., Marston, J.B., Moritz, M.A., Prentice, I.C., Roos, C.I., Scott, A.C., Swetnam, T.W., van der Werf, G.R., Pyne, S.J., 2009. Fire in the Earth system. Science, 324, 481-484.

Bradstock, R.A., 2010. A biogeographic model of fire regimes in Australia: current and future implications. Global Ecology and Biogeography, 19, 145-158.

Bradstock, R.A., Williams, R.J., 2009. Can Australian fire regimes be managed for carbon benefits? New Phytologist, 183, 931-934.

Bradstock, R.A., Hammill, K.A., Collins, L., Price, O., 2009. Effects of weather, fuel and terrain on fire severity in topographically diverse landscapes of south-eastern Australia. Landscape Ecology, 25, 607-619.

Broncano, M.J., Retana, J., 2004. Topography and forest composition affecting the variability in fire severity and post-fire regeneration occurring after a large fire in the Mediterranean basin. International Journal of Wildland Fire, 13, 209-216.

Carvalho, A., Flannigan, M.D., Logan, K.A., Gowman, L.M., Miranda, A.I., Borrego, C., 2010. The impact of spatial resolution on area burned and fire occurrence projections in Portugal under climate change. Climatic Change, 98, 177-197.

Catry, F., Rego, F., Moreira, F., Fernandes, P.M., Pausas, J., 2010. Post-fire tree mortality in mixed forests of central Portugal. Forest Ecology and Management, 260, 1184-1192.

Cochrane, M.A., Moran, C.J., Wimberly, M.C., Baer, A.D., Finney, M.A., Beckendorf, K.L., Eidenshink, J., Zhu, Z., 2012. Estimation of wildfire size and risk changes due to fuel treatments. International Journal of Wildland Fire, 21, 357-367.

Collins, B.M., Miller, J.D., Thode, A.E., Kelly, M., van Wagtendonk, J.W., Stephens, S.L., 2009. Interactions among wildland fires in a long-established Sierra Nevada natural fire area. Ecosystems, 12, 114-128.

Collins, B.M., Stephens, S.L., Moghaddas, J.J., Battles, J., 2010. Challenges and approaches in planning fuel treatments across fire-excluded forested landscapes. Journal of Forestry, 108, 24-31.

Cruz, M., Alexander, M., 2010. Assessing crown fire potential in coniferous forests of western North America: a critique of current approaches and recent simulation studies. International Journal of Wildland Fire, 19, 377-398.

Cruz, M., Alexander, M., Fernandes, P., 2008. Development of a model system to predict wildfire behaviour in pine plantations. Australian Forestry, 71, 113-121.

Díaz-Delgado, R., Lloret, F., Pons, X., 2004. Statistical analysis of fire frequency models for Catalonia (NE Spain, 1975-1998) based on fire scar maps from Landsat MSS data. International Journal of Wildland Fire, 13, 89-99.

Duguy, B., Alloza, J.A., Röder, A., Vallejo, R., Pastor, F., 2007. Modelling the effects of landscape fuel treatments on fire growth and behaviour in a Mediterranean landscape (eastern Spain). International Journal of Wildland Fire, 16, 619-632.

Dury, M., Hambuckers, A., Warnant, P., Henrot, A., Favre, E., Ouberdous, M., François, L., 2011. Responses of European forest ecosystems to 21st century climate: assessing changes in interannual variability and fire intensity. iForest 4, 82-99 [online: 2011-04-07] URL: http://www.sisef.it/iforest/show.php?id=572

EFI, 2010. A Mediterranean Forest Research Agenda - MFRA. European Forest Institute, Joensuu.

Epting, J., Verbyla, D., 2005. Landscape-level interactions of prefire vegetation, burn severity, and postfire vegetation over a 16-year period in interior Alaska. Canadian Journal of Forest Research 35, 1367-1377.

Faiella, S.M., Bailey, J., 2007. Fluctuations in fuel moisture across restoration treatments in semi-arid ponderosa pine forests of northern Arizona, USA. International Journal of Wildland Fire 16, 119-127.

Fernandes, P.M., 2008. Forest fires in Galicia (Spain): the outcome of unbalanced fire management. Journal of Forest Economics, 14, 155-157. 
Fernandes, P.M., 2009a. Examining fuel treatment longevity through experimental and simulated surface fire behaviour: a maritime pine case study. Canadian Journal of Forest Research, 39, 2529-2535.

Fernandes, P., 2009b. Combining forest structure data and fuel modelling to assess fire hazard in Portugal. Annals of Forest Science, 66, 415p1-415p9.

Fernandes, P.M., Botelho, H.S., 2003. A review of prescribed burning effectiveness in fire hazard reduction. International Journal of Wildland Fire, 12, 117-128.

Fernandes, P.M., Loureiro, C., Magalhães, M., Ferreira, P., Fernandes, M., 2012. Fuel age, weather and burn probability in Portugal. International Journal of Wildland Fire, 21, 380-384.

Fernandes, P., Loureiro, C., Botelho, H., 2004. Fire behaviour and severity in a maritime pine stand under differing fuel conditions. Annals of Forest Science, 61, 537-544.

Fernandes, P., Luz, A., Loureiro, C., 2010. Changes in wildfire severity from maritime pine woodland to contiguous forest types in the mountains of northwestern Portugal. Forest Ecology and Management, 260, 883-892.

Fernandes, P.M., Rigolot, E., 2007. The fire ecology and management of maritime pine (Pinus pinaster Ait.). Forest Ecology and Management, 241, 1-13.

Finney, M.A., 2001. Design of regular landscape fuel treatment patterns for modifying fire growth and behavior. Forest Science, 47, 219-228.

Finney, M.A., McHugh, C.W., Grenfell, I.C., 2005. Stand- and landscape-level effects of prescribed burning on two Arizona wildfires. Canadian Journal of Forest Research, 35, 1714-1722.

Finney, M.A., Seli, R.C., McHugh, C.W., Ager, A.A., Bahro, B., Agee, J.K., 2007. Simulation of long-term landscapelevel fuel treatment effects on large wildfires. International Journal of Wildland Fire, 16, 712-727.

Flannigan, M.D., Krawchuk, M.A., de Groot, W.J., Wotton, B.M., Gowman, L.M., 2009. Implications of changing climate for global wildland fire. International Journal of Wildland Fire, 18, 483-507.

Fox, B.J., Fox, M.D., 1987. The role of fire in scleromorphic forests and shrublands of eastern Australia, in: Trabaud, L. (Ed.), The Role of Fire in Ecological Systems, SPB Academic Publishing, The Hague. pp. 2348.

Fulé, P., Ribas, M., Gutiérrez, E., Vallejo, R., Kaye, M., 2008. Forest structure and fire history in an old Pinus nigra forest, eastern Spain. Forest Ecology and Management, 255, 1234-1242.

Gill, A.M., 2005. Landscape fires as social disasters: An overview of 'the bushfire problem'. Environmental Hazards, 6, 65-80.

Gill, A.M., Stephens, S.L., 2009. Scientific and social challenges for the management of fire-prone wildlandurban interfaces. Environmental Research Letters, 4, 034014.

González, J., Kolehmainen, 0., Pukalla, T., 2007a. Using expert knowledge to model forest stand vulnerability to fire. Computers and Electronics in Agriculture, 55, 107-114.

González, J., Palahi, M., Trasobares, A., Pukalla, T., 2006. A fire probability model for forest stands in Catalonia (north-east Spain). Annals of Forest Science, 63, 169-176.

González, J.R., Trasobares, A., Palahi, M., Pukkala, T., 2007b. Predicting stand damage and tree survival in burned forests in Catalonia (North-East Spain). Annals of Forest Science, 64, 733-742.

González-Olabarria, J., Pukkala, T., 2011. Integrating fire risk considerations in landscape-level forest planning. Forest Ecology and Management, 261, 278-287.

Gould, J., McCaw, L., Cheney, P., Ellis, P., Knight, I., Sullivan, A., 2007. Project Vesta - Fire in dry eucalypt forest: fuel structure, fuel dynamics and fire behaviour. Ensis-CSIRO and Department of Environment and Conservation, Canberra, ACT, and Perth, WA.

Graham, R., McCaffrey, S., Jain, T. (Tech. Eds.), 2004. Science basis for changing forest structure to modify wildfire behavior and severity. Gen. Tech. Rep. RMRS-GTR-120. USDA Forest Service, Fort Collins.

Hessl, A.E., 2011. Pathways for climate change effects on fire: models, data, and uncertainties. Progress in Physical Geography, 35, 393-407.

Hirsch, K., Kafka, V., Tymstra, C., McAlpine, R., Hawkes, B., Stegehuis, H., Quintilio, S., Gauthier, S., Peck, K., 2001. Fire-smart forest management: a pragmatic approach to sustainable forest management in firedominated ecosystems. The Forestry Chronicle, 77, 1-7.

Hurteau, M.D., Stoddard, M.T., Fulé, P.Z., 2011. The carbon costs of mitigating high-severity wildfire in southwestern ponderosa pine. Global Change Biology, 17, 1516-1521.

Keeley, J., Zedler, P., 2009. Large, high-intensity fire events in southern California shrublands: debunking the fine-grain age patch model. Ecological Applications, 19, 69-94. 
Keeley, J.E., Aplet, G.H., Christensen, N.L., Conard, S.G., Johnson, E.A., Omi, P.N., Peterson, D.L., Swetnam, T.W., 2009. Ecological Ffoundations for fire management in North American forest and shrubland ecosystems. USDA Forest Service, Pacific Northwest Research Station, General Technical Report PNW-GTR-779.

King, K.J., Bradstock, R.A., Cary, G.J., Chapman, J., Marsden-Smedley, J.B. 2008. The relative importance of finescale fuel mosaics on reducing fire risk in south-west Tasmania, Australia. International Journal of Wildland Fire, 17, 421-430.

Kolström, M., Vilén, T., Lindner, M., 2011. Climate change impacts and adaptation in European forests. EFI Policy Brief 6. European Forest Institute, Joensuu, Finland.

Koutsias, N., Arianoutsou, M., Kallimanis, A.S., Mallinis, G., Halley, J.M., Dimopoulos, P., 2012. Where did the fires burn in Peloponnisos, Greece the summer of 2007? Evidence for a synergy of fuel and weather. Agricultural and Forest Meteorology, 156, 41-53.

Krawchuk, M.A., Moritz, M.A., Parisien, M.-A., Van Dorn, J., Hayhoe, K., 2009. Global pyrogeography: the current and future distribution of wildfire. PLoS ONE 4, e5102.

Loepfe, L., Martinez-Vilalta, J., Oliveres, J., Piñol, J., Lloret, F., 2010. Feedbacks between fuel reduction and landscape homogenization determine fire regimes in three Mediterranean areas. Forest Ecology and Management, 249, 2366-2374.

Ma, S., Concilio, A., Oakley, B., North, M., Chen, J., 2009. Spatial variability in microclimate in a mixed-conifer forest before and after thinning and burning treatments. Forest Ecology and Management, 259, 904-915.

Macias Fauria, M., Michaletz, S.T., Johnson, E.A., 2011. Predicting climate change effects on wildfires requires linking processes across scales. WIREs Climate Change, 2, 99-112.

Marino, E., Guijarro, M., Hernando, C., Madrigal, J., Díez, C., 2011. Fire hazard after prescribed burning in a gorse shrubland: implications for fuel management. Journal of Environmental Management, 92, 10031011.

McCaw, W.L., Gould, J.S., Cheney, N.P., Ellis, P.F.M., Anderson, W.R., 2012. Changes in behaviour of fire in dry eucalypt forest as fuel increases with age. Forest Ecology and Management, 271, 170-181.

Millar, C.I., Stephenson, N.L., Stephens, S.L., 2007. Climate change and forests of the future: managing in the face of uncertainty. Ecological Applications, 17, 2145-2151.

Moreira, F., Duarte, L., Catry, F., Acácio, V., 2007. Cork extraction as a key factor determining post-fire cork oak survival in a mountain region of southern Portugal. Forest Ecology and Management, 253, 30-37.

Moreira, F., Vaz, P., Catry, F., Silva, J., 2009. Regional variations in wildfire susceptibility of land-cover types in Portugal: implications for landscape management to minimize fire hazard. International Journal of Wildland Fire, 18, 563-574.

Moreira, F., Viedma, O., Arianoutsou, M., Curt, T., Koutsias, N., Rigolot, E., Barbati, A., Corona, P., Vaz, P., Xanthopoulos, G., Mouillot, F., Bilgili, E., 2011. Landscape - wildfire interactions in southern Europe: implications for landscape management. Journal of Environmental Management, 92, 2389-2402.

Moreno, J.M., Viedma, O., Zavala, G., Luna, B., 2011. Landscape variables influencing forest fires in central Spain. International Journal of Wildland Fire, 20, 678-689.

Moriondo, M., Good, P., Durão, R., Bindi, M., Giannakopoulos, C., Corte-Real, J., 2006. Potential impact of climate change on fire risk in the Mediterranean area. Climate Research, 31, 85-95.

Moritz, M.A., Keeley, J.E., Johnson, E.A., Schaffner, A.A., 2004. Testing a basic assumption of shrubland fire management: how important is fuel age? Frontiers in Ecology and the Environment, 2, 67-72.

Moritz, M.A., Stephens, S.L., 2008. Fire and sustainability: considerations for California's altered future climate. Climatic Change, 87, S265-S271.

Narayan, C., Fernandes, P.M., van Brusselen, J., Schuck, A., 2007. Potential for $\mathrm{CO}_{2}$ emissions mitigation through prescribed burning in the context of the Kyoto Protocol. Forest Ecology and Management, 251, 164-173.

Nassauer, J.I., 2012. Landscape as medium and method for synthesis in urban ecological design. Landscape and Urban Planning, 106, 221-229.

O'Donnell, A.J., Boer, M.M., McCaw, W.L., Grierson, P.F., 2011. Vegetation and landscape connectivity control wildfire intervals in unmanaged semi-arid shrublands and woodlands in Australia. Journal of Biogeography, 38, 112-124.

Oliveira, S.L.J., Pereira, J.M.C., Carreiras, 2012. Fire frequency analysis in Portugal (1975-2005), using Landsatbased burnt area maps. International Journal of Wildland Fire, 21, 48-60. 
Oliveras, I., Gracia, M., Moré, G., Retana, J., 2009. Factors influencing the pattern of fire severities in a large wildfire under extreme meteorological conditions in the Mediterranean basin. International Journal of Wildland Fire, 18, 755-764.

Osborne, C.P., Mitchell, P.L., Sheehy, J.E., Woodward, F.I., 2000. Modelling the recent historical impacts of atmospheric $\mathrm{CO}_{2}$ and climate change on Mediterranean vegetation. Global Change Biology, 6, 445-458.

Pausas, J.G., Bradstock, R.A., 2007. Fire persistence traits of plants along a productivity and disturbance gradient in Mediterranean shrublands of SE Australia. Global Ecology and Biogeography, 16, 330-340.

Pausas, J.G., Fernández-Muñoz, S., 2012. Fire regime changes in the Western Mediterranean Basin: from fuellimited to drought-driven fire regime. Climatic Change, 110, 215-226.

Pausas, J.G., Paula, S., 2012. Fuel shapes the fire-climate relationship: evidence from Mediterranean ecosystems. Global Ecology and Biogeography. DOI: 10.1111/j.1466-8238.2012.00769.x

Pausas, J.G., Llovet, J., Rodrigo, A., Vallejo, R., 2008. Are wildfires a disaster in the Mediterranean basin? - A review. International Journal of Wildland Fires, 17, 713-723.

Pechony, O., Shindell, D.T., 2010. Driving forces of global wildfires over the past millennium and the forthcoming century. PNAS, 1003669107v1-4.

Perchat, S., Rigolot, E., 2005. Comportement au feu et utilisation par les forces de lutte des coupures de combustible touches par les grands incendies de la saison 2003 (Fuel-breaks affected by large fires in 2003: fire behaviour and use by fire suppression). Ed. de la Cardère, Morières. [in French]

Piñol, J., Castellnou, M., Beven, K.J., 2007. Conditioning uncertainty in ecological models: assessing the impact of fire management strategies. Ecological Modelling, 207, 34-44.

Pook, E.W., Gill, A.M., 1993. Variation of live and dead fine fuel moisture in Pinus radiata plantations of the Australian Capital Territory. International Journal of Wildland Fire, 3, 155-168.

Price, O.F., Bradstock, R.A., 2010. The effect of fuel age on the spread of fire in sclerophyll forest in the Sydney region of Australia. International Journal of Wildland Fire, 19, 35-45.

Price, O.F., Bradstock, R.A., 2011. Quantifying the influence of fuel age and weather on the annual extent of unplanned fires in the Sydney region of Australia. International Journal of Wildland Fire, 20, 142-151.

Prichard, S.J., Peterson, D.L., Jacobson, K., 2010. Fuel treatments reduce the severity of wildfire effects in dry mixed conifer forest, Washington, USA. Canadian Journal of Forest Research, 40, 1615-1626.

Proença, V.M, Pereira, H.M., Vicente, L., 2010. Resistance to wildfire and early regeneration in natural broadleaved forest and pine plantation. Acta Oecologica, 36, 626-633.

Pyne, S.J., Andrews, P.L., Laven, R.D., 1996. Introduction to Wildland Fire. 2nd edn. John Wiley and Sons, New York.

Raymond, C.L., Peterson, D.L., 2005. Fuel treatments alter the effects of wildfire in a mixed-evergreen forest, Oregon, USA. Canadian Journal of Forest Research, 35, 2981-2995.

Reams, M.A., Haines, T.K., Renner, C.R., Wascom, M.W., Kingre, H., 2005. Goals, obstacles and effective strategies of wildfire mitigation programs in the Wildland-Urban interface. Forest Policy and Economics, 7, 818-826.

Reinhardt, E.D., Keane, R.E., Calkin, D.E., Cohen, J.D., 2008. Objectives and considerations for wildland fuel treatment in forested ecosystems of the interior western United States. Forest Ecology and Management, 256, 1997-2006.

Resco de Dios, V., Fischer, C., Colinas, C., 2007. Climate change effects on mediterranean forests and preventive measures. New Forests, 33, 29-40.

Róman-Cuesta, R.M., Gracia, M., Retana, J., 2009. Factors influencing the formation of unburned forest islands within the perimeter of a large fire. Forest Ecology and Management, 258, 71-80.

Safford, H.D., Stevens, J.T., Merriam, K., Meyer, M.D., Latimer, A.M., 2012. Fuel treatment effectiveness in California yellow pine and mixed conifer forests. Forest Ecology and Management, 274, 17-28.

Scarascia-Mugnozza, G., Oswald, H., Piussi, P., Radoglou, K., 2000. Forests of the Mediterranean region: gaps in knowledge and research needs. Forest Ecology and Management, 132, 97-109.

Schaffhauser, A., Curt, T., Tatoni, T., 2011. Fire-vegetation interplay in a mosaic structure of Quercus suber woodlands and Mediterranean maquis under recurrent fires. Forest Ecology and Management, 262, 730738.

Schelhaas, M.J., Hengeveld, G., Moriondo, M., Reinds, G., Kundzewicz, Z., Maat, H., Bindi, M., 2010. Assessing risk and adaptation options to fires and windstorms in European forestry. Mitigation and Adaptation Strategies for Global Change, 15, 681-701.

Seidl, R., Schelhaas, M-J., Lexer, M.J., 2011. Unravelling the drivers of intensifying forest disturbance regimes 
in Europe. Global Change Biology, 17, 2842-2852.

Stephens, S.L., Fry, D.L., Franco-Vizcaíno, E., 2008. Wildfire and spatial patterns in forests in northwestern Mexico: the United States wishes it had similar fire problems. Ecology and Society, 13, 10. [online] URL: http://www.ecologyandsociety.org/vol13/iss2/art10/

Stephens, S.L., Fulé, P.Z., 2005. Western pine forests with continuing frequent fire regimes: Possible reference sites for management. Journal of Forestry, 103, 357-362.

Stephens, S., Millar, C., Collins, B., 2010. Operational approaches to managing forests of the future in Mediterranean regions within a context of changing climates. Environmental Research Letters, 5, 024003.

Strom, B.A., Fulé, P.Z., 2007. Pre-wildfire fuel treatments affect long-term ponderosa pine forest dynamics. International Journal ofWildland Fire, 16, 128-138.

Syphard, A.D., Keeley, J.E., Brennan, T., 2011. Comparing the role of fuel breaks across southern California national forests. Forest Ecology and Management, 261, 2038-2048.

Thonicke, K., Spessa, A., Prentice, I.C., Harrison, S.P., Dong, L., Carmona-Moreno, C., 2010. The influence of vegetation, fire spread and fire behaviour on biomass burning and trace gas emissions: results from a process-based model. Biogeoscience, 7, 1991-2011.

Van Wilgen, B.W., Forsyth, G.G., De Klerk, H., Das, S., Khuluse, S., Schmitz, P., 2010. Fire management in Mediterranean-climate shrublands: a case study from the Cape fynbos, South Africa. Journal of Applied Ecology, 47, 631-638.

Vega, J., Jimenez, E., Vega, D., Ortiz, L., Pérez, J.R., 2011. Pinus pinaster Ait. tree mortality following wildfire in Spain. Forest Ecology and Management, 12, 2232-2242.

Verburg, P.H., Berkel, D.B., Doorn, A.M., Eupen, M., Heiligenberg, H., 2010. Trajectories of land use change in Europe: a model-based exploration of rural futures. Landscape Ecology, 25, 217-232.

Viedma, O., Angeler, D.G., Moreno, J.M., 2009. Landscape structural features control fire size in a Mediterranean forested area of central Spain. International Journal of Wildland Fire, 18, 575-583.

Vilén, T., Fernandes, P.M., 2011. Forest fires in Mediterranean countries: $\mathrm{CO}_{2}$ emissions and mitigation possibilities through prescribed burning. Environmental Management, 48, 558-567.

Xanthopoulos, G., Caballero, D., Galante, M., Alexandrian, D., Rigolot, E., Marzano, R., 2006. Forest fuels management in Europe, in: Andrews, P.L., Butler, B.W. (Comps.), Fuels management - how to measure success: conference proceedings, Proceedings RMRS-P-41, USDA Forest Service, Rocky Mountain Research Station. Fort Collins, CO. pp. 29-46. 